\title{
Acute effects of air pollutants on pulmonary function among students: a panel study in an isolated island
}

\author{
Yoshiko Yoda', Hiroshi Takagi ${ }^{2}$, Junko Wakamatsu², Takeshi Ito², Ryouhei Nakatsubo ${ }^{3}$, Yosuke Horie ${ }^{3}$,
} Takatoshi Hiraki ${ }^{3}$ and Masayuki Shima ${ }^{1 *}$ (D)

\begin{abstract}
Background: Many epidemiological studies on the health effects of air pollutants have been carried out in regions with major sources such as factories and automobiles. However, the health effects of air pollutants in regions without major sources remain unclear. This study investigated the acute effects of ambient air pollution on pulmonary function among healthy students in an isolated island without major artificial sources of air pollutants.

Methods: A panel study was conducted of 43 healthy subjects who attended a school in an isolated island in the Seto Inland Sea, Japan. We measured the forced expiratory volume in $1 \mathrm{~s}\left(\mathrm{FEV}_{1}\right)$ and peak expiratory flow (PEF) every morning for about 1 month in May 2014. Ambient concentrations of particulate matter $\leq 2.5 \mu \mathrm{m}$ in diameter $\left(\mathrm{PM}_{2.5}\right)$, particulate matter between 2.5 and $10 \mu \mathrm{m}$ in diameter $\left(\mathrm{PM}_{10-2.5}\right)$, black carbon $(\mathrm{BC})$, ozone $\left(\mathrm{O}_{3}\right)$, and nitrogen dioxide $\left(\mathrm{NO}_{2}\right)$ were measured. The associations between the concentrations of air pollutants and pulmonary function were analyzed using mixed-effects models.

Results: A decrease in $\mathrm{FEV}_{1}$ was significantly associated with BC concentrations $(-27.28 \mathrm{~mL}$ [95\%confidence interval (Cl): $-54.10,-0.46]$ for an interquartile range (IQR) increase of $\left.0.23 \mu \mathrm{g} / \mathrm{m}^{3}\right)$. The decrease in PEF was significantly associated with indoor $\mathrm{O}_{3}$ concentrations (-8.03 L/min [95\% Cl:-13.02,-3.03] for an IQR increase of $11 \mathrm{ppb}$ ). Among subjects with a history of allergy, an increase in $\mathrm{PM}_{2.5}$ concentrations was significantly associated with low $\mathrm{FEV}_{1}$. In subjects with a history of asthma, an inverse association between the indoor $\mathrm{O}_{3}$ concentration and pulmonary function was observed.

Conclusions: Our results demonstrate that increases in $\mathrm{BC}$ and $\mathrm{O}_{3}$ concentrations have acute effects on the pulmonary function among students in an isolated island without major artificial sources of air pollutants.
\end{abstract}

Keywords: Allergy, Asthma, Air pollution, Isolated island, Pulmonary function, Panel study

\section{Background}

Many studies have reported the influence of air pollutants on the respiratory system [1-7]. Among air pollutants, particulate matter $\leq 2.5 \mu \mathrm{m}$ in diameter $\left(\mathrm{PM}_{2.5}\right)$ induces an inflammatory response of the airway when inhaled, reducing the pulmonary function [8-11]. In addition, it is known that exposure to black carbon (BC), a component of $\mathrm{PM}_{2.5}$, impairs the lung function in children [12]. Many studies involving patients with respiratory diseases, such as asthma [13-15] and chronic obstructive pulmonary

\footnotetext{
* Correspondence: shima-m@hyo-med.ac.jp

${ }^{1}$ Department of Public Health, Hyogo College of Medicine, 1-1

Mukogawa-cho, Nishinomiya, Hyogo 663-8501, Japan

Full list of author information is available at the end of the article
}

disease (COPD) [16, 17], have been carried out to evaluate the acute effects of air pollution. In addition, these studies have been primarily conducted in urban areas with a high concentration of air pollutants, involving factories and automobiles $[18,19]$. Furthermore, most studies adopted concentrations at monitoring stations in the neighborhood to evaluate the influence of air pollutants on the respiratory system.

However, the results of studies among patients with specific diseases or epidemiological studies in areas with a high concentration of air pollutatnts are not always adaptable for a general population. Few epidemiological studies have evaluated the health effects of changes in the concentration of air pollutants in an environment 
where healthy persons live. Furthermore, the duration of indoor daily activities is longer than that of outdoor activities; therefore, when concentrations at monitoring stations in the neighborhood were used, exposure assessment may not have been accurately performed.

In this study, we repeatedly performed pulmonary function tests of healthy subjects in an isolated island without major artificial sources of air pollutants, and evaluated the acute effects of changes in the concentrations of air pollutants measured in indoor and outdoor spaces on the respiratory system among the subjects.

\section{Methods}

\section{Study design and subjects}

Yuge Island is an isolated island in the Seto Inland Sea, Japan (Fig. 1). Pulmonary function tests among students were conducted every day between May 12 and June 9, 2014. In addition, the atmospheric environment was measured during the same period. On this island, road traffic is light, but there may be little influence of automobile exhausts. Furthermore, there is no large factory, and there are no artificial sources of air pollutants other than ships; the island may be a clean-air area. However, recently, the influence of transported air pollutants derived from the Asian Continent has been indicated [20]. To investigate the relationship between the atmospheric environment and pulmonary function, we conducted pulmonary function tests among subjects who had stayed in Yuge Island over a long period of time; students attending a school on this island were requested to participate in this study. The subjects were 43 students from whom written informed consent was obtained (aged 15-16 years, mean: 15.1 years, 29 males and 14 females). Prior to this study, its protocol was

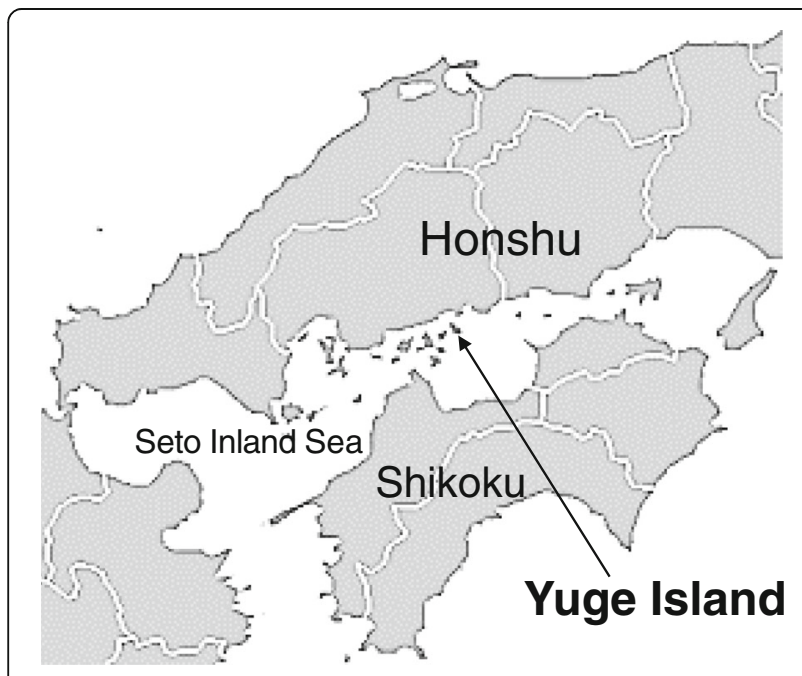

Fig. 1 Location of Yuge Island in the Seto Inland Sea of Japan approved by the Ethics Review Board of Hyogo College of Medicine.

\section{Assessment of the effects on health}

Using a standard questionnaire [21], respiratory symptoms and the presence or absence of a history of asthma or allergy were evaluated. Subjects who selected "Yes" to the question "Have you ever been diagnosed with asthma?" were regarded as having a history of asthma. Those who selected "Yes" to the question "Have you ever been diagnosed with allergic rhinitis?" or "Have you ever been diagnosed with pollinosis?" were regarded as having a history of allergy.

For pulmonary function testing, an electronic peak flow meter (Vitalograph 2110, Vitalograph Ltd., Buckingham, U.K.) was delivered to each subject, and self-measurement of the peak expiratory flow (PEF) and forced expiratory volume in $1 \mathrm{~s}\left(\mathrm{FEV}_{1}\right)$ was conducted before the start of the first lesson every morning from Monday until Friday.

\section{Measurement of the atmospheric environment}

To measure the atmospheric environment, an automatic particulate matter-measuring device (SPM-613D, Kimoto Electric Co., Ltd., Osaka, Japan) was installed on the roof of the school, and $\mathrm{PM}_{2.5}$, particulate matter between 2.5 and $10 \mu \mathrm{m}$ in diameter $\left(\mathrm{PM}_{10-2.5}\right)$, and $\mathrm{BC}$ were measured continuously. In addition, the outdoor concentrations of ozone $\left(\mathrm{O}_{3}\right)$ and nitric oxide $\left(\mathrm{NO}_{2}\right)$ were measured using a passive sampler (Ogawa \& Co., Ltd., Kobe, Japan) and a filter badge $\mathrm{NO}_{2}$ (Advantec Co. Ltd., Tokyo, Japan), respectively. The sampler and badge were exchanged every $24 \mathrm{~h}$ on Monday to Friday for measurement, and 72-h measurement was conducted on weekends. Furthermore, the indoor concentrations of $\mathrm{O}_{3}$ and $\mathrm{NO}_{2}$ were measured in school classrooms, where the students had stayed for most of each school day, as described for outdoor measurement. The indoor concentration of $\mathrm{PM}_{2.5}$ was measured serially using a digital dust indicators (Model LD-5, Sibata Scientific Technology Ltd., Tokyo, Japan) in the classroom.

\section{Statistical analysis}

The relationships between the indoor and outdoor concentrations of $\mathrm{PM}_{2.5}, \mathrm{O}_{3}$, and $\mathrm{NO}_{2}$ were expressed as correlation coefficients. Those between the results of a pulmonary function test and the concentrations of air pollutants were evaluated using a mixed effect model with the rate of change per interquartile range (IQR) increase of each pollutant for $24 \mathrm{~h}$ before a pulmonary function test after adjusting for the atmospheric temperature, humidity, and subject's height. Furthermore, the analyses were performed using two-pollutant models to adjust for potential confounding effects of co-pollutants, for outdoor 
and indoor air pollutants, respectively. A $p$-value of 0.05 was regarded as significant. For analysis, we used SPSS 22 software (IBM Co., Armonk, NY, U.S.A.).

\section{Results}

The background characteristics of the subjects are shown in Table 1. A total of 868 pulmonary function tests were conducted. The means \pm standard deviations of PEF and $\mathrm{FEV}_{1}$ were $390.1 \pm 110.2 \mathrm{~L} / \mathrm{min}$ and $2.48 \pm$ $0.74 \mathrm{~L}$, respectively. Of the subjects, $7(16.3 \%)$ had a history of asthma, and 19 (44.2\%) had a history of allergy without asthma. Seventeen subjects (39.5\%) did not have either history. During the study period, no subject developed respiratory symptoms, such as cough, sputum, or wheezing.

The mean daily indoor/outdoor concentrations of air pollutants during the study period are shown in Table 2 . The mean outdoor concentration of $\mathrm{PM}_{2.5}$ was $30.9 \pm$ $12.5 \mu \mathrm{g} / \mathrm{m}^{3}$. Those of $\mathrm{PM}_{10-2.5}$ and $\mathrm{BC}$ were $22.7 \pm 15.4$ and $0.55 \pm 0.22 \mu \mathrm{g} / \mathrm{m}^{3}$, respectively. The maximum outdoor concentration of $\mathrm{PM}_{2.5}$ was $61.6 \mu \mathrm{g} / \mathrm{m}^{3}$, which was measured on the day with yellow sand carried from China to Japan. On the same day, the concentration of $\mathrm{PM}_{10-2.5}$ was also high $\left(53.8 \mu \mathrm{g} / \mathrm{m}^{3}\right)$. The mean indoor concentration of $\mathrm{PM}_{2.5}$ was $17.0 \pm 9.6 \mu \mathrm{g} / \mathrm{m}^{3}$.

There were strong positive correlations between the outdoor and indoor concentrations of $\mathrm{PM}_{2.5}$ and $\mathrm{NO}_{2}$ $(r=0.82$ and 0.92 , respectively). However, the correlation between those of $\mathrm{O}_{3}$ was weak $(r=0.42)$ (Fig. 2). The mean indoor concentrations of $\mathrm{PM}_{2.5}, \mathrm{O}_{3}$, and $\mathrm{NO}_{2}$ were lower than the outdoor values.

The associations between the concentrations of air pollutants and changes in parameters of pulmonary function during the study period are shown in Table 3. $\mathrm{FEV}_{1}$ decreased significantly in relation to an increase in the $\mathrm{BC}$ concentration $(-27.28 \mathrm{~mL}$ [95\% confidence interval (CI):-54.10,-0.46] per IQR increase of $0.23 \mu \mathrm{g} / \mathrm{m}^{3}$ ). The PEF reduced significantly in relation to an increase in the indoor $\mathrm{O}_{3}$ concentration $(-8.03 \mathrm{~L} / \mathrm{min}[95 \%$ CI:-13.02,-3.03] per IQR increase of $11.0 \mathrm{ppb})$. There was no significant correlation between the concentrations of the other pollutants and changes in pulmonary function.

Table 1 Characteristics of study subjects

\begin{tabular}{llll}
\hline & $\begin{array}{l}\text { Male } \\
(n=29)\end{array}$ & $\begin{array}{l}\text { Female } \\
(n=14)\end{array}$ & $\begin{array}{l}\text { Total } \\
(n=43)\end{array}$ \\
\hline Height, mean (SD) (cm) & $166.4 \pm 6.8$ & $156.9 \pm 5.1$ & $163.3 \pm 7.7$ \\
PEF (L/min) & $420.8 \pm 110.2$ & $320.7 \pm 73.7$ & $390.1 \pm 110.2$ \\
$\mathrm{FEV}_{1}(\mathrm{~L})$ & $2.66 \pm 0.75$ & $2.10 \pm 0.55$ & $2.48 \pm 0.74$ \\
$\begin{array}{l}\text { Measurements of } \\
\text { pulmonary function (n) }\end{array}$ & $(594)$ & $(274)$ & $(868)$ \\
\hline
\end{tabular}

$S D$ standard deviation; PEF peak expiratory flow; $F E V_{1}$, forced expiratory volume in $1 \mathrm{~s}$
We performed analyses using two-pollutant models to adjust for confounding effects of co-pollutants. Additional file 1: Table S1 shows the estimated changes in PEF and $\mathrm{FEV}_{1}$ associated with an IQR increase of each pollutant [see Additional file 1]. The $\mathrm{FEV}_{1}$ showed a significant decrease in relation to an increase in $\mathrm{BC}$ after adjustment for outdoor $\mathrm{O}_{3}$. The association between PEF and indoor $\mathrm{O}_{3}$ was also significant after adjustment for indoor $\mathrm{PM}_{2.5}$ or $\mathrm{NO}_{2}$. Furthermore, PEF reduced significantly in relation to an increase in outdoor $\mathrm{PM}_{2.5}$ or $\mathrm{BC}$, after adjustment for outdoor $\mathrm{NO}_{2}$.

The associations between the concentrations of air pollutants and PEF with respect to the presence or absence of a history of asthma or allergy are shown in Fig. 3(a). In subjects with a history of allergy, PEF reduced significantly with an increase in the indoor concentration of $\mathrm{PM}_{2.5}(-6.71 \mathrm{~L} / \mathrm{min}$ [95\% CI:-13.36, -0.06] per IQR increase). In those with a history of asthma, PEF reduced significantly with an increase in the indoor concentration of $\mathrm{O}_{3}(-22.6 \mathrm{~L} / \mathrm{min}$ [95\% CI:-41.08,-4.13] per IQR increase). On the other hand, the PEF reduced significantly with an increase in the indoor concentration of $\mathrm{O}_{3}$ in those without either history $(-8.84 \mathrm{~L} / \mathrm{min}$ [95\% CI:-16.28,-1.40] per IQR increase). In those with a history of allergy, $\mathrm{FEV}_{1}$ reduced significantly with an increase in the outdoor concentration of $\mathrm{PM}_{2.5}(-70.0 \mathrm{~mL}$ [95\% CI:-130.1,-9.94] per IQR increase) (Fig. 3(b)). In addition, $\mathrm{FEV}_{1}$ reduced significantly with an increase in the indoor concentration of $\mathrm{O}_{3}$ in subjects with a history of asthma $(-130.3 \mathrm{~mL}$ [95\% CI:-243.5,-17.2] per IQR increase).

\section{Discussion}

Even in an isolated island without artificial sources of air pollutants, there were changes in the atmospheric concentrations of air pollutants, indicating that changes in the concentration of $\mathrm{BC}$ have an acute influence on the pulmonary function in healthy students. The indoor concentration of $\mathrm{O}_{3}$ more markedly influenced pulmonary function compared with its outdoor concentration. In subjects with a history of asthma, pulmonary function reduced significantly with an increase in $\mathrm{O}_{3}$ concentration. In those with a history of allergy, it reduced significantly with an increase in $\mathrm{PM}_{2.5}$ concentration. These results suggested that subjects with these histories were more susceptible to changes in the concentrations of air pollutants.

Although we thought that this island in the Seto Inland Sea should be a clean-air area, the concentration of $\mathrm{PM}_{2.5}$ was considerably high in the island. It was thought that the high concentrations recorded were largely due to transported air pollutants including yellow sand and the emissions from marine ships. Allen et al. showed that 
Table 2 The 24-h mean concentrations of outdoor and indoor air pollutants and meteorological parameters during the study period

\begin{tabular}{|c|c|c|c|c|c|c|c|}
\hline & $n$ & Mean & SD & Minimum & Median & Maximum & IQR \\
\hline \multicolumn{8}{|l|}{ Outdoor air pollutants } \\
\hline $\mathrm{PM}_{2.5}\left(\mu \mathrm{g} / \mathrm{m}^{3}\right)$ & 29 & 30.9 & 12.5 & 13.7 & 30.6 & 61.6 & 18.4 \\
\hline $\mathrm{PM}_{10-2.5}\left(\mu \mathrm{g} / \mathrm{m}^{3}\right)$ & 29 & 22.7 & 15.4 & 6.0 & 16.2 & 54.2 & 24.2 \\
\hline$B C\left(\mu \mathrm{g} / \mathrm{m}^{3}\right)$ & 29 & 0.55 & 0.22 & 0.26 & 0.49 & 1.25 & 0.23 \\
\hline $\mathrm{O}_{3}(\mathrm{ppb})$ & 21 & 44.6 & 10.3 & 25.7 & 46.1 & 58.5 & 20.8 \\
\hline $\mathrm{NO}_{2}(\mathrm{ppb})$ & 21 & 9.2 & 3.8 & 4.2 & 8.6 & 16.7 & 6.3 \\
\hline \multicolumn{8}{|l|}{ Indoor air pollutants } \\
\hline $\mathrm{PM}_{2.5}\left(\mu \mathrm{g} / \mathrm{m}^{3}\right)$ & 29 & 17.0 & 9.6 & 3.7 & 16.5 & 39.3 & 12.6 \\
\hline $\mathrm{O}_{3}(\mathrm{ppb})$ & 21 & 15.9 & 7.5 & 1.9 & 16.2 & 30.0 & 11.0 \\
\hline $\mathrm{NO}_{2}(\mathrm{ppb})$ & 21 & 6.3 & 3.0 & 2.2 & 5.8 & 15.3 & 4.2 \\
\hline \multicolumn{8}{|c|}{ Meteorological parameters } \\
\hline Temperature $\left({ }^{\circ} \mathrm{C}\right)$ & 29 & 20.2 & 2.1 & 15.8 & 19.8 & 23.9 & 3.6 \\
\hline Relative humidity (\%) & 29 & 71.5 & 11.1 & 52.0 & 69.0 & 92.0 & 15.5 \\
\hline
\end{tabular}

$S D$ standard deviation; IQR interquartile range; $P M_{2.5}$ particulate matter $\leq 2.5 \mu \mathrm{m}$ in diameter; $P M_{10-2.5}$ particulate matter between 2.5 and $10 \mu \mathrm{m}$ in diameter; $B C$ black carbon; $\mathrm{O}_{3}$ ozone; $\mathrm{NO}_{2}$ nitrogen dioxide

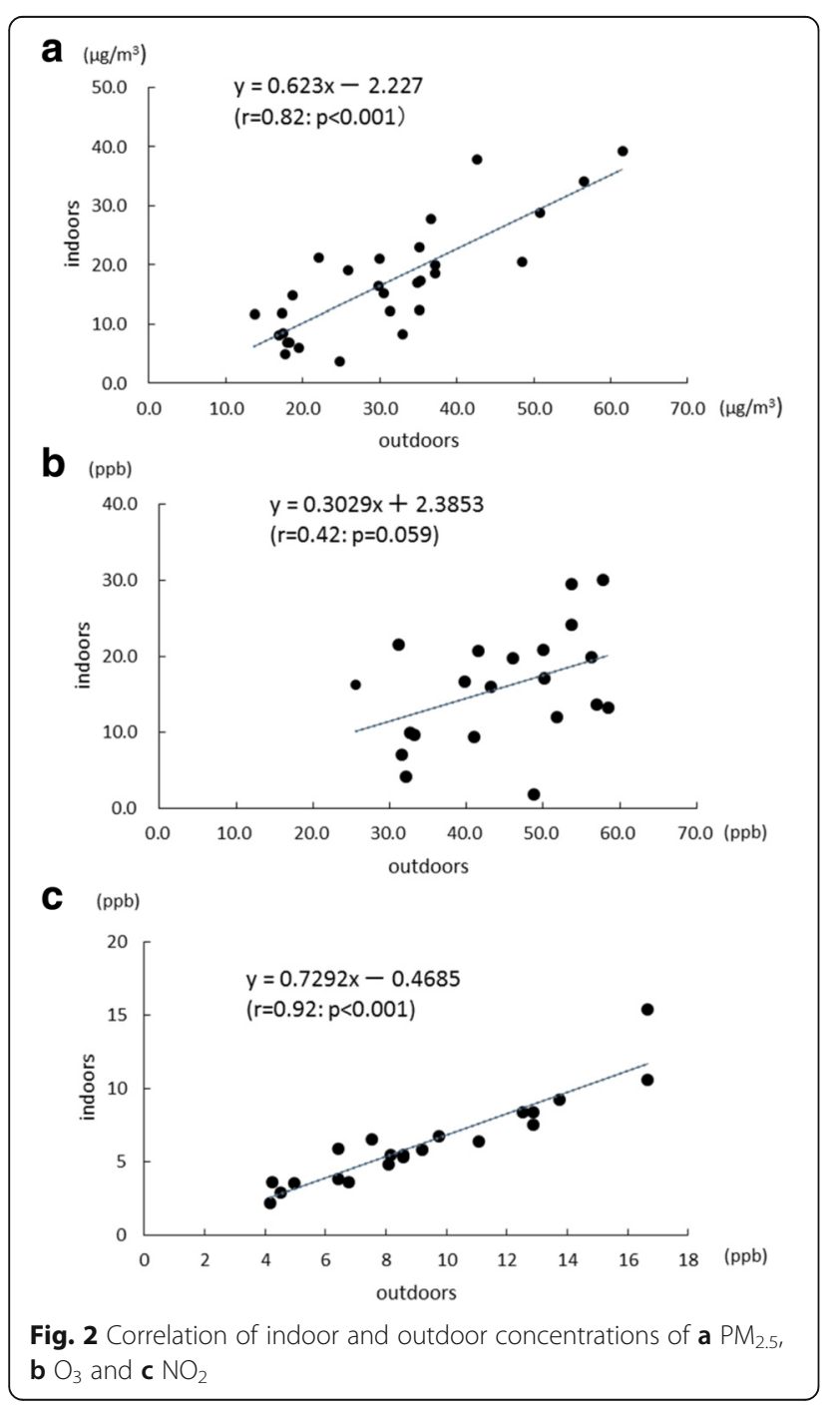

$\mathrm{PM}_{2.5}$ are transported over long distances and affects distant clean-air areas [22]. It was also reported that transported air pollutants and emissions from marine ships affect the levels of air pollution in Kyushu, Japan [23, 24]. If the emission from marine ships contribute to air quality in the island, the concentration of sulfur dioxide may be also high. However, the concentrations have not been measured around the island.

The results of this study showed that pulmonary function reduced significantly with an increase in the atmospheric concentration of $\mathrm{BC}$, and the association was still significant after adjustment for $\mathrm{O}_{3}$. Huang et al. reported that a pulmonary function test in healthy adults after they stayed in a transport hub of a big city for $2 \mathrm{~h}$ showed a significant decrease in $\mathrm{FEV}_{1}$ related to an increase in BC concentration [25]. Patel et al. conducted a study among school children in New York, and indicated that symptoms, such as wheezing and shortness of breath, deteriorated with an increase in $\mathrm{BC}$ concentration [26]. The results of these studies were consistent with those of our study. Diesel emission gas contains a large volume of $B C$ [27]. A study reported that when persons were exposed to diesel emission gas, the bronchial mucosal neutrophil and mast cell counts increased, inducing transient increases in the number of inflammatory cells in the airway and cytokine levels [28]. With an increase in $\mathrm{BC}$ concentration, an inflammatory response in the airway may have occurred, thereby reducing pulmonary function. The area investigated in this study was an isolated island with light traffic, which unlike urban areas, and had relatively low concentration of $\mathrm{BC}$. Our results suggested that an increase in $\mathrm{BC}$ concentration influences pulmonary function even in such an area with a low air pollutant concentrations. Huang et al. evaluated adults 
Table 3 Associations between air pollutants and pulmonary function during the study period

\begin{tabular}{|c|c|c|c|c|c|c|}
\hline & \multicolumn{3}{|c|}{$\mathrm{PEF}(\mathrm{L} / \mathrm{min})$} & \multicolumn{3}{|l|}{$\mathrm{FEV}_{1}(\mathrm{~mL})$} \\
\hline & Change $^{a}$ & $95 \% \mathrm{Cl}$ & $P$-Value & Change $^{a}$ & $95 \% \mathrm{Cl}$ & P-Value \\
\hline \multicolumn{7}{|c|}{ Outdoor air pollutants } \\
\hline $\mathrm{PM}_{2.5}$ & -4.57 & $(-10.67,1.52)$ & 0.141 & -41.19 & $(-84.38,1.99)$ & 0.062 \\
\hline $\mathrm{PM}_{10-2.5}$ & -2.71 & $(-9.04,3.62)$ & 0.401 & -37.50 & $(-81.80,6.79)$ & 0.097 \\
\hline$B C$ & -3.53 & $(-7.31,0.25)$ & 0.067 & -27.28 & $(-54.10,-0.46)$ & 0.046 \\
\hline $\mathrm{O}_{3}$ & -3.84 & $(-15.42,7.74)$ & 0.515 & -30.93 & $(-112.84,50.99)$ & 0.459 \\
\hline $\mathrm{NO}_{2}$ & 2.18 & $(-3.67,8.02)$ & 0.466 & -28.23 & $(-69.40,12.95)$ & 0.179 \\
\hline \multicolumn{7}{|c|}{ Indoor air pollutants } \\
\hline $\mathrm{PM}_{2.5}$ & -3.21 & $(-8.63,2.20)$ & 0.245 & -9.58 & $(-48.50,29.34)$ & 0.629 \\
\hline $\mathrm{O}_{3}$ & -8.03 & $(-13.02,-3.03)$ & 0.002 & -20.14 & $(-55.36,15.09)$ & 0.262 \\
\hline $\mathrm{NO}_{2}$ & 0.81 & $(-3.96,5.59)$ & 0.738 & -9.88 & $(-43.22,23.46)$ & 0.561 \\
\hline
\end{tabular}

PEF peak expiratory flow; $F E V_{1}$ forced expiratory volume in $1 \mathrm{~s} ; C l$ confidence interval; $P M_{2.5}$ particulate matter $\leq 2.5 \mu \mathrm{m}$ in diameter; $P M_{10-2.5}$ particulate matter between 2.5 and $10 \mu \mathrm{m}$ in diameter; $\mathrm{BC}$ black carbon; $\mathrm{O}_{3}$ ozone; $\mathrm{NO}_{2}$ nitrogen dioxide

${ }^{\mathrm{a}}$ Mean changes in $\mathrm{PEF}$ or $\mathrm{FEV}_{1}$ associated with an increase in the interquartile range of each air pollutant

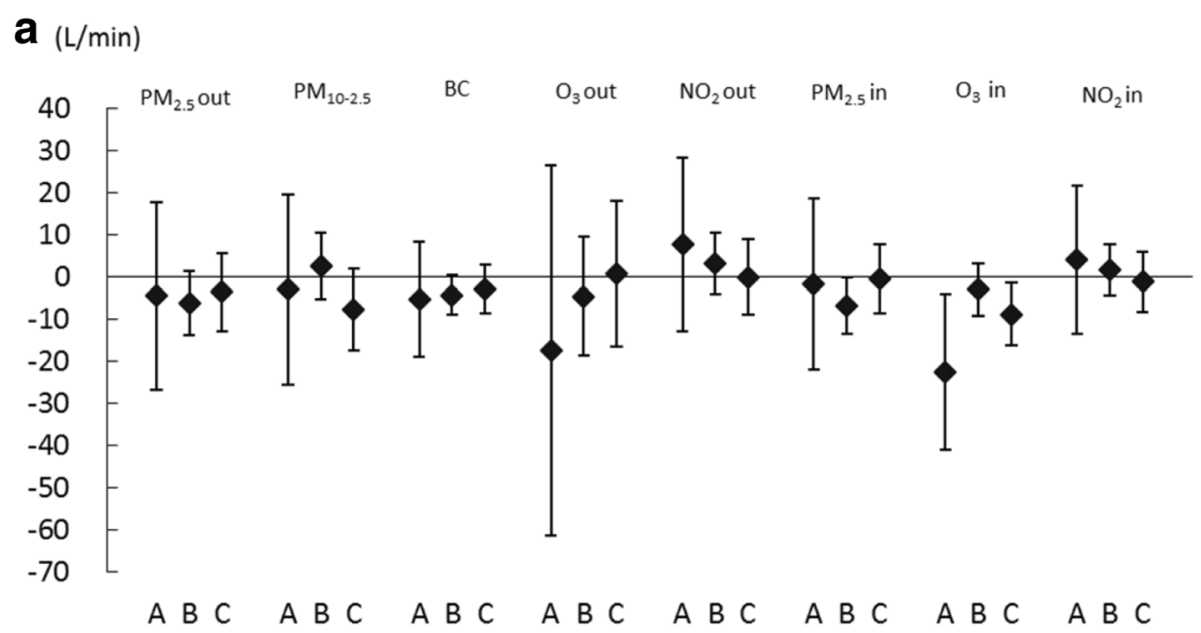

$\mathbf{b}_{(\mathrm{mL})}$

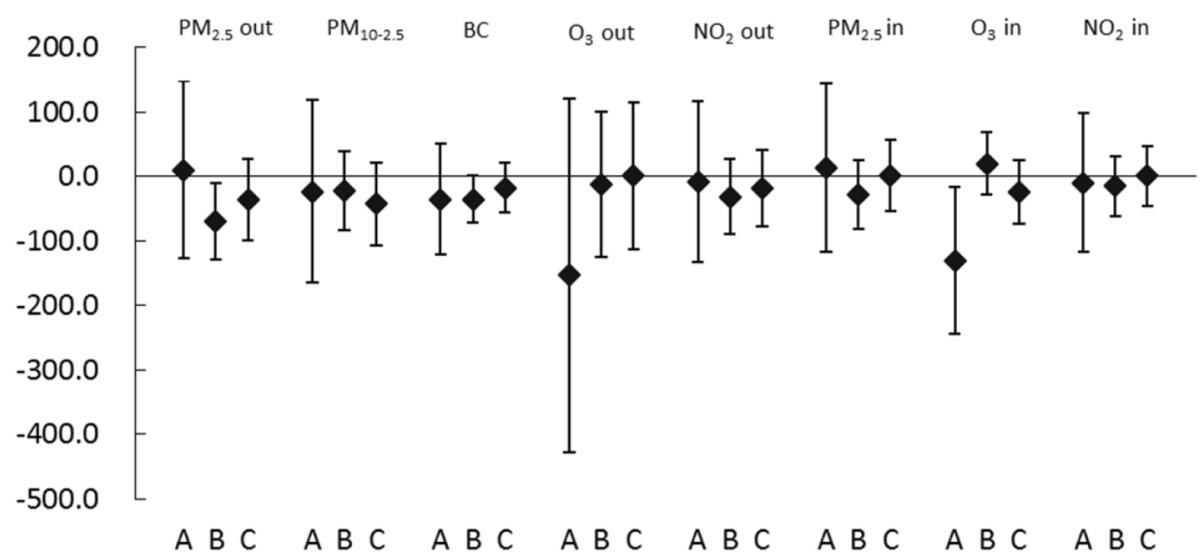

Fig. 3 Estimated changes in (a) PEF and (b) $\mathrm{FEV}_{1}$ with increases in air pollutants in relation to a history of asthma or allergy. The estimated changes and 95\% confidence intervals for (a) PEF and (b) FEV 1 are shown per increase in interquartile range (IQR) of the concentration of air pollutants in relation to a history of asthma or allergy. A: Subjects with a history of asthma. B: Subjects with a history of allergy other than asthma. C: Subjects without a history of asthma or allergy 
exposed to air pollutants for $2 \mathrm{~h}$ in a previous study [25]. In our study, the subjects were adolescent students who attended school for many hours. Because this survey was conducted in an isolated island, the subjects resided both in the island and along the coast. As the 1-month survey was carried out in such a place, the influence of exposure to air pollutants on daily living could be evaluated accurately. Furthermore, most subjects were healthy, and the results of our study may be representative.

The indoor concentration of $\mathrm{O}_{3}$ was more markedly associated with pulmonary function compared with its outdoor concentration, and the effect of $\mathrm{O}_{3}$ was still significant after adjustment for $\mathrm{PM}_{2.5}$ or $\mathrm{NO}_{2}$. $\mathrm{O}_{3}$ exhibits acute effects on the lungs [29]. When the indoor concentration of $\mathrm{O}_{3}$ increased, PEF decreased significantly. However, there was no significant relationship with an increase in the outdoor concentration of $\mathrm{O}_{3}$. Altug et al. reported that the PEF among elementary school children decreased significantly with an increase in the concentration of $\mathrm{O}_{3}$ [30]. McConnell et al. performed a 5-year follow-up survey of 3535 children without asthma, and indicated that 265 were newly diagnosed with asthma during the follow-up, suggesting that high-intensity exercise in an area with a high concentration of $\mathrm{O}_{3}$ promotes the onset of childhood asthma [31]. Furthermore, Amadeo et al. reported that, even at an $\mathrm{O}_{3}$ concentration lower than the reference value presented in the WHO guidelines, PEF decreased with an increase in the concentration of $\mathrm{O}_{3}$, suggesting the acute effects of $\mathrm{O}_{3}$ on the pulmonary function of children [32]. Pulmonary function reduces with an increase in $\mathrm{O}_{3}$ concentration, because $\mathrm{O}_{3}$ may increase inflammation of the airway as a potent acidic pollutant $[10,33]$. Intra-pulmonary $\mathrm{O}_{3}$ uptake was reported to peak in the terminal bronchioles [34]. In our study, the relationship with the indoor concentration of $\mathrm{O}_{3}$ and pulmonary function was marked. Gaseous substances, such as $\mathrm{O}_{3}$, are sometimes generated indoors; therefore, their concentrations in living spaces should be measured and used for exposure assessments.

Neither the indoor nor outdoor concentrations of $\mathrm{PM}_{2.5}$ were significantly associated with PEF and $\mathrm{FEV}_{1}$ among all the subjects in a single-pollutant model. However, after adjustment for outdoor $\mathrm{NO}_{2}$, PEF significantly decreased with an increase in the outdoor concentration of $\mathrm{PM}_{2.5}$. Moreover, PEF decreased significantly with an increase in $\mathrm{BC}$ after adjustment for $\mathrm{NO}_{2}$. These findings may be due to the interactions between $\mathrm{NO}_{2}$ and other air pollutants. The results suggested acute effects related to changes in the concentrations of $\mathrm{O}_{3}$ and $\mathrm{PM}_{2.5}$ in subjects with a history of asthma or allergy. In those with a history of allergy, the PEF and $\mathrm{FEV}_{1}$ significantly reduced when the indoor and outdoor concentrations of $\mathrm{PM}_{2.5}$ increased, respectively. With respect to the acute effects of $\mathrm{PM}_{2.5}$, Huang et al. reported that $\mathrm{FEV}_{1}$ decreased by-0.15\% (95\% CI:-0.28,-0.02\%) when the exposure concentration for $2 \mathrm{~h}$ increased by $10 \mu \mathrm{g} / \mathrm{m}^{3}$ [25]. Bernals et al. indicated that allergic airway diseases are not merely disorders of the immune system, and that allergic diseases primarily arise from airway epithelium defects resulting from immaturity or caused by environmental insults [35]. In our study, pulmonary function may also have reduced through such a pathophysiological mechanism. Based on the results of this study, there was no relationship between $\mathrm{PM}_{10-2.5}$ and changes in pulmonary function. $\mathrm{PM}_{10-2.5}$ is deposited in the nasal cavity, pharynx, and upper airway when it is inhaled. However, $\mathrm{PM}_{2.5}$ reaches the bronchiolar and alveolar levels in the lungs because its particle diameter is small. A previous study reported that the influence of $\mathrm{PM}_{2.5}$ on the respiratory system was more marked than that of $\mathrm{PM}_{10-2.5}$ [36]. Based on the results of this study, there was no relationship between the $\mathrm{PM}_{2.5}$ concentration and PEF or $\mathrm{FEV}_{1}$ in subjects with a history of asthma, but this was possibly because the number of subjects was small.

In subjects with a history of asthma, PEF and FEV 1 decreased significantly with an increase in the indoor concentration of $\mathrm{O}_{3}$. In these subjects, the two parameters decreased slightly with an increase in the outdoor concentration of $\mathrm{O}_{3}$. Mortimer et al. reported that PEF in the morning decreased with an increase in $\mathrm{O}_{3}$ concentration in children with asthma [37]. In our study, when analyzing the results with respect to medical histories, PEF was associated with an increase in $\mathrm{O}_{3}$ concentration in subjects other than those with a history of allergy. There was no significant difference in those with a history of allergy, but the reason was unclear.

There was no association between an increase in $\mathrm{NO}_{2}$ concentration and pulmonary function. In power plant workers exposed to $\mathrm{NO}_{2}$, pulmonary functions were reduced significantly [38]. Gauderman et al. indicated that the odds ratio of asthma was 1.83 (95\% CI: 1.04-3.22) when the outdoor concentration of $\mathrm{NO}_{2}$ increased by $5.7 \mathrm{ppb}$ (IQR) [39]. Furthermore, Liu et al. conducted a study among children with asthma, and reported that an increase in $\mathrm{NO}_{2}$ concentration significantly reduced pulmonary function [40]. The concentration of $\mathrm{NO}_{2}$ measured in our study was relatively low; therefore, there may have been no influence on the respiratory system.

We had conducted the survey in the same area in the autumn of 2013, and found negative associations between pulmonary function and the concentrations of $\mathrm{PM}_{2.5}, \mathrm{NO}_{2}$, and $\mathrm{BC}$ among subjects with a history of asthma [41]. In the present study, to estimate the exposure to air pollutants accurately, we conducted measurements of the indoor concentrations of air pollutants in addition to outdoor concentrations. The subjects in the present study were different from those in the previous 
one, and this survey was conducted during spring. In the results of this study, an inverse association between pulmonary function and the concentrations of air pollutants among subjects with a history of asthma or allergy, which was compatible with the previous study. Therefore, subjects with a history of asthma or allergy were considered to be more susceptible to air pollutants. These adverse effects of air pollution may be modified by medication for asthma or allergy. However, in this study, information on the medication taken by the subjects was not obtained. The interaction with medication should be further evaluated.

This study has several limitations. One is that the number of subjects was small, resulting in an insufficient detection power; therefore, the influence of air pollution may have been underestimated. However, pulmonary function tests were conducted every morning, and a significant reduction in pulmonary function related to increases in $\mathrm{BC}$ or $\mathrm{O}_{3}$ concentrations was observed, even though the number of subjects was relatively small. The second limitation is that the study period was short and was limited to one season. It has been reported that the concentrations and sources of air pollutants have seasonal variations. In the future, a large-scale survey involving a larger number of subjects should be conducted for a longer period. The third limitation is that only PEF and $\mathrm{FEV}_{1}$ were used as pulmonary function parameters. Although inflammation of the airway may be involved in a reduction of pulmonary function, it was not tested in this study. In the future, the inflammatory state of the airway should be evaluated objectively in addition to pulmonary function tests.

\section{Conclusion}

In an isolated island without major artificial sources of air pollutants, changes in the concentrations of air pollutants acutely influenced the pulmonary function of healthy subjects. The results suggest that gaseous substances, such as $\mathrm{O}_{3}$, are sometimes generated indoors, and that the indoor concentration of $\mathrm{O}_{3}$ more markedly influences pulmonary function compared with its outdoor concentration. In subjects with a history of allergy, pulmonary function reduced with an increase in the concentration of $\mathrm{PM}_{2.5}$.

\section{Additional file}

Additional file 1: Table S1. Associations between air pollutants and pulmonary function during the study period in each single- and two-pollutant model. (DOCX $23 \mathrm{~kb})$

\section{Abbreviations}

$\mathrm{BC}$ : Black carbon; FEV ${ }_{1}$ : Forced expiratory volume in $1 \mathrm{~s}$; IQR: Interquartile range; $\mathrm{NO}_{2}$ : Nitrogen dioxide; $\mathrm{O}_{3}$ : Ozone; PEF: Peak expiratory flow; $\mathrm{PM}_{10}$

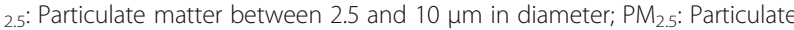
matter $\leq 2.5 \mu \mathrm{m}$ in diameter

\section{Acknowledgements}

The authors would like to thank the staff of the National Institute of Technology, Yuge College for their technical support. We also acknowledge the participation of the students of the College.

\section{Funding}

This research was supported by the Environment Research and Technology Development Fund (5-1456) of the Ministry of the Environment, Japan.

\section{Availability of data and materials}

The datasets used and analyzed during the current study are available from the corresponding author on reasonable request.

\section{Authors' contributions}

MS was the research leader of this study. YY, HT, JW and MS designed the study. HT, JW and TI performed pulmonary function tests among students. $\mathrm{RN}, \mathrm{YH}$ and TH conducted measurement of the atmospheric environment. YY performed the statistical analyses and wrote the first draft of this manuscript, and MS revised it to make the final manuscript. All authors have approved the final manuscript.

\section{Competing interests}

The authors declare that they have no competing interests.

\section{Consent for publication}

Not applicable.

\section{Ethics approval and consent to participate}

This study was approved by the Ethics Review Board of Hyogo College of Medicine (17-May-2013, approval number 1474). The objectives and methods of this study were fully explained to all participants, and written, informed consent was obtained from each participant before the study.

\section{Publisher's Note}

Springer Nature remains neutral with regard to jurisdictional claims in published maps and institutional affiliations.

\section{Author details}

${ }^{1}$ Department of Public Health, Hyogo College of Medicine, 1-1 Mukogawa-cho, Nishinomiya, Hyogo 663-8501, Japan. ${ }^{2}$ National Institute of Technology, Yuge College, Kamijima, Ehime, Japan. ${ }^{3}$ Hyogo Prefectural Institute of Environmental Sciences, Kobe, Hyogo, Japan.

Received: 17 November 2016 Accepted: 20 March 2017

Published online: 04 April 2017

References

1. Brunekreef B, Holgate ST. Air pollution and health. Lancet. 2002;360:1233-42.

2. Rice MB, Ljungman PL, Wilker EH, Gold DR, Schwartz JD, Koutrakis $P$, et al. Short-term exposure to air pollution and lung function in the Framingham Heart Study. Am J Respir Crit Care Med. 2013;188:1351-7.

3. Bell ML. Assessment of the health impacts of particulate matter characteristics. Res Rep Health Eff Inst. 2012;161:5-38.

4. Chang YK, Wu CC, Lee LT, Lin RS, Yu YH, Chen YC. The short-term effects of air pollution on adolescent lung function in Taiwan. Chemosphere. 2012;87: 26-30.

5. Schindler C, Kunzli N, Bongard JP, Leuenberger P, Karrer W, Rapp R, et al. Short-term variation in air pollution and in average lung function among never-smokers. The Swiss Study on Air Pollution and Lung Diseases in Adults (SAPALDIA). Am J Respir Crit Care Med. 2001;163:356-61.

6. Jacobson Lda S, Hacon Sde S, de Castro HA, Ignotti E, Artaxo P, Saldiva PH, et al. Acute effects of particulate matter and black carbon from seasonal fires on peak expiratory flow of schoolchildren in the Brazilian Amazon. PLOS One. 2014;9:e104177

7. Yoda Y, Otani N, Sakurai S, Shima M. Acute effects of summer air pollution on pulmonary function and airway inflammation in healthy young women. J Epidemiol. 2014:24:312-20.

8. Churg A, Brauer M, del Carmen Avila-Casado M, Fortoul TI, Wright JL. Chronic exposure to high levels of particulate air pollution and small airway remodeling. Environ Health Perspect. 2003;111:714-8. 
9. Xing YF, XU YH, Shi MH, Lian YX. The impact of PM2.5 on the human respiratory system. J Thorac Dis. 2016;8:E69-74.

10. Barraza-Villarreal A, Sunyer J, Hernandez-Cadena L, Escamilla-Nunez MC, Sienra-Monge JJ, Ramirez-Aguilar M, et al. Air pollution, airway inflammation, and lung function in a cohort study of Mexico City schoolchildren. Environ Health Perspect. 2008;116:832-8.

11. Koenig JQ, Jansen K, Mar TF, Lumley T, Kaufman J, Trenga CA, et al. Measurement of offline exhaled nitric oxide in a study of community exposure to air pollution. Environ Health Perspect. 2003;111:1625-9.

12. Kulkarni N, Pierse N, Rushton L, Grigg J. Carbon in airway macrophages and lung function in children. N Engl J Med. 2006;355:21-30.

13. Sarnat SE, Raysoni AU, Li WW, Holguin F, Johnson BA, Flores Luevano S, et al. Air pollution and acute respiratory response in a panel of asthmatic children along the U.S.-Mexico border. Environ Health Perspect. 2012;120: 437-44.

14. Qian Z, Lin HM, Chinchilli VM, Lehman EB, Stewart WF, Shah N, et al. Associations between air pollution and peak expiratory flow among patients with persistent asthma. J Toxicol Environ Health A. 2009;72:39-46.

15. Mann JK, Balmes JR, Bruckner TA, Mortimer KM, Margolis HG, Pratt B, et al. Short-term effects of air pollution on wheeze in asthmatic children in Fresno, California. Environ Health Perspect. 2010;118:1497-502.

16. Wu S, Ni Y, Li H, Pan L, Yang D, Baccarelli AA, et al. Short-term exposure to high ambient air pollution increases airway inflammation and respiratory symptoms in chronic obstructive pulmonary disease patients in Beijing, China. Environ Int. 2016;94:76-82.

17. Lagorio S, Forastiere F, Pistelli R, lavarone I, Michelozzi P, Fano V, et al. Air pollution and lung function among susceptible adult subjects: a panel study. Environ Health. 2006;5:11.

18. Holguin F, Flores S, Ross Z, Cortez M, Molina M, Molina L, et al. Trafficrelated exposures, airway function, inflammation, and respiratory symptoms in children. Am J Respir Crit Care Med. 2007;176:1236-42.

19. Patel MM, Chillrud SN, Deepti KC, Ross JM, Kinney PL. Traffic-related air pollutants and exhaled markers of airway inflammation and oxidative stress in New York City adolescents. Environ Res. 2013;121:71-8.

20. Lim HJ, Turpin BJ, Russell LM, Bates TS. Organic and elemental carbon measurements during ACE-Asia suggest a longer atmospheric lifetime for elemental carbon. Environ Sci Technol. 2003;37:3055-61.

21. Ferris BG. Epidemiology Standardization Project (American Thoracic Society). Am Rev Respir Dis. 1978;118:1-120.

22. Allen AG, Nemitz E, Shi JP, Harrison RM, Greenwood JC. Size distributions of trace metals in atmospheric aerosols in the United Kingdom. Atmos Environ. 2001;35:4581-91.

23. Kanaya Y, Taketani F, Irie H, Komazaki Y, Takashima H, Uno I. PM2.5 mass concentrations observed at Fukue Island, Kyushu, Japan: Exceeding the atmospheric environment standard. J Jpn Soc Atmos Environ. 2010;45(6): 289-92.

24. Suzuki R, Yoshino A, Kaneyasu N, Takami A, Hayashi M, Hara K, et al. Characteristics and source apportionment of trace metals in the aerosols at Fukue Island and Fukuoka City. J Jpn Soc Atmos Environ. 2014;49:15-25 [in Japanese].

25. Huang J, Deng F, Wu S, Zhao Y, Shima M, Guo B, et al. Acute effects on pulmonary function in young healthy adults exposed to traffic-related air pollution in semi-closed transport hub in Beijing. Environ Health Prev Med. 2016; doi:10.1007/s12199-016-0531-5.

26. Patel MM, Chillrud SN, Correa JC, Hazi Y, Feinberg M, Kc D, et al. Trafficrelated particulate matter and acute respiratory symptoms among New York City area adolescents. Environ Health Perspect. 2010;118:1338-43.

27. World Health Organization. Health effects of black carbon. Copenhagen: WHO Regional Office for Europe. 2012;23-33.

28. Behndig AF, Mudway IS, Brown JL, Stenfors N, Helleday R, Duggan ST, et al. Airway antioxidant and inflammatory responses to diesel exhaust exposure in healthy humans. Eur Respir J. 2006;27:359-65.

29. Society CotEaOHAotAT. Health effects of outdoor air pollution. Committee of the Environmental and Occupational Health Assembly of the American Thoracic Society. Am J Respir Crit Care Med. 1996;153:3-50.

30. Altug H, Gaga EO, Dogeroglu T, Brunekreef B, Hoek G, Van Doorn W. Effects of ambient air pollution on respiratory tract complaints and airway inflammation in primary school children. Sci Total Environ. 2014;479-480:201-9.

31. McConnell R, Berhane K, Gilliland F, London SJ, Islam T, Gauderman WJ, et al. Asthma in exercising children exposed to ozone: a cohort study. Lancet. 2002;359:386-91.
32. Amadeo B, Robert C, Rondeau V, Mounouchy MA, Cordeau L, Birembaux X, et al. Impact of close-proximity air pollution on lung function in schoolchildren in the French West Indies. BMC Public Health. 2015;15:45.

33. Berhane K, Zhang Y, Linn WS, Rappaport EB, Bastain TM, Salam MT, et al. The effect of ambient air pollution on exhaled nitric oxide in the Children's Health Study. Eur Respir J. 2011;37:1029-36.

34. Miller FJ, Overton JH, Jaskot RH, Menzel DB. A model of the regional uptake of gaseous pollutants in the lung. I. The sensitivity of the uptake of ozone in the human lung to lower respiratory tract secretions and exercise. Toxicol Appl Pharmacol. 1985;79:11-27.

35. Bernard A, Nickmilder M, Dumont X. Airway epithelium defects and risks of allergic diseases: multiple associations revealed by a biomarker study among adolescents. Am J Respir Crit Care Med. 2015;191:714-7.

36. World Health Organization. Air quality guidelines - global update 2005. Copenhagen: WHO Regional Office for Europe; 2006.

37. Mortimer KM, Neas LM, Dockery DW, Redline S, Tager IB. The effect of air pollution on inner-city children with asthma. Eur Respir J. 2002;19:699-705.

38. Carbone U, Montuori P, Novi C, Triassi M. Respiratory function in power plant workers exposed to nitrogen dioxide. Occup Med (Lond). 2014; doi:10.1093/occmed/kqu129.

39. Gauderman WJ, Avol E, Lurmann F, Kuenzli N, Gilliland F, Peters J, et al. Childhood asthma and exposure to traffic and nitrogen dioxide. Epidemiology. 2005;16:737-43.

40. Liu L, Poon R, Chen L, Frescura AM, Montuschi P, Ciabattoni G, et al. Acute effects of air pollution on pulmonary function, airway inflammation, and oxidative stress in asthmatic children. Environ Health Perspect. 2009;117: $668-74$.

41. Yoda Y, Takagi H, Wakamatu J, Otani N, Shima M. Short-term effects of air pollutants on pulmonary function in adolescent with a history of asthma or allergies. Jap J Allergology [Arerugi]. 2015;64:128-35 [in Japanese].

\section{Submit your next manuscript to BioMed Central and we will help you at every step:}

- We accept pre-submission inquiries

- Our selector tool helps you to find the most relevant journal

- We provide round the clock customer support

- Convenient online submission

- Thorough peer review

- Inclusion in PubMed and all major indexing services

- Maximum visibility for your research

Submit your manuscript at www.biomedcentral.com/submit
Biomed Central 